\title{
Gründercamp ga mersmak
}

\section{En spennende læringsmetode og god arena for samarbeid mellom utdanning og praksis.}

samarbeid med Skedsmo kommune og Ungt Entreprenørskap Akershus, arrangerte Høgskolen i Oslo og Akershus studiested Kjeller, for første gang gründercamp for førsteårsstudenter i sykepleie i november 2012.

\section{Tettere bånd}

Entreprenøriell læring er en god pedagogisk form for å skape muligheter til indre motivasjon, engasjement, mestring og drivkraft som sykepleierstudenter vil kunne dra nytte av, både gjennom studiet og som ferdige sykepleiere. Gjennom samarbeidet med praksis håper vi at denne måten å tenke på skal bidra til endrete arbeidsmåter og innovasjon på våre praksissteder. Dette er også en flott måte å knytte tettere bånd til våre praksisfelt.

De store utfordringene sykepleietjenesten står overfor i årene som kommer, krever at vi som sykepleiere er kreative, nyskapende og tenker samarbeid i større grad enn i dag. Det er behov for å utdanne en ny generasjon helsepersonell, som fokuserer mer på helsefremmende og forebyggende arbeid.

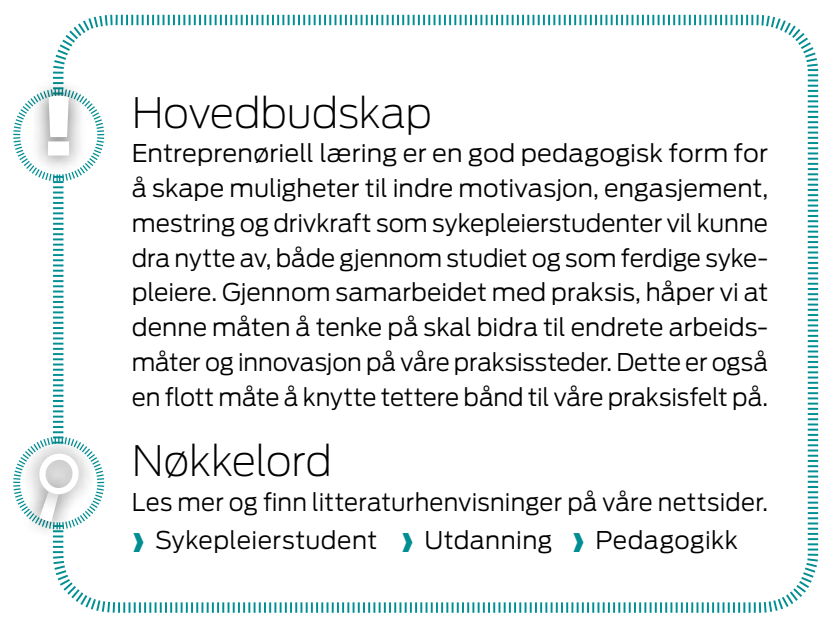

De fleste undersøkelser viser at det gjennomgående blir gitt et godt helse- og pleietilbud i den kommunale omsorgstjenesten. De samme undersøkelsene viser imidlertid at helsepersonell ikke i like stor grad bidrar til å skape sosialt fellesskap og en meningsfull hverdag (1). I lys av samhandlingsreformen og de utfordringer eldreomsorgen står overfor i årene som kommer, ga vår samarbeidspartner, Skedsmo kommune, studentene et oppdrag med temaet «verdighetsgarantien».

\section{Kreativt}

Gründercamp er en treningsleir for kreativitet og nyskaping. Studentene får et reelt oppdrag med en definert problemstilling, som de skal presentere en løsning på innen et avgrenset tidsrom. Denne måten å jobbe på gjør det mulig for den enkelte student å utvikle sitt potensial for å bli en god og kreativ sykepleier i fremtiden. Gründercamp bidrar også til samarbeid på tvers av egen institusjon.

En annen positiv bieffekt er at studentene må presentere forslaget sitt for en jury. Dette gir god trening for senere å skulle undervise eller informere pasienter i større og mindre grupper.

\section{Utdanningskrav}

Gjennom innføring av kvalifikasjonsrammeverket for høyere utdanning, skal innovasjons- og nyskapingskompetanse være integrert $i$ alle fagområder på alle nivåer innen 2012 (2). Det er derfor viktig at vi som høyskole arbeider med innovasjon og entreprenørskap i sykepleieutdanningen, og tester ut ulike modeller for dette.

I universitets- og høyskoleloven § 1-3 a, kreves det at utdanningsinstitusjonens virksomhet skal fremme lovens formål ved «å tilby høyere utdanning som er basert på det fremste innen forskning, faglig og kunstnerisk utviklingsarbeid og erfaringskunnskap» (3). Dette inkluderer bruk av entreprenøriell læring som pedagogisk plattform for å utvikle innovasjon og nyskapningskompetanse hos den enkelte student. Vi har dermed plikt til å utdanne en ny generasjon helsepersonell med større fokus på helsefremmende og forebyggende arbeid som fremmer folkehelsen (4). Erfaringene fra gründercampen har overbevist oss om at dette er en riktig satsing for å møte morgendagens utfordringer.

\section{Oppdraget}

Oppdragsgiver Skedsmo kommune ønsket gode innspill til hvordan man kan tilrettelegge for en verdig alderdom, med fokus på sosiale relasjoner og opplevelser på sykehjemmene i Skedsmo.

Studentene ble oppfordret til å ta utgangspunkt i praksisperioden de nettopp hadde vært i, og bruke verdighetsgarantien til å identifisere en situasjon eller hendelse som representerer et forbedringsområde innen sykehjemstjenesten. Studentene skulle gjøre rede for et tiltak som sikrer et bedre tjenestetilbud basert på at den enkelte skal få en verdig alderdom og anledning til livsutfoldelse i samsvar med egne muligheter og grunnleggende behov.

\section{Gjennomføring}

Gründercampen varte i to dager. Dette gav studentene mulighet til å utvikle ideen sin utover kvelden på første dag, etter å ha vært i veiledning. I tillegg ble det tid til både kreativitetsøvelser og inspirasjonsforedrag.

Juryene hadde en utfordrende oppgave med å velge ut finalistene blant de sytten forslagene. Det var mange gode kandidater og stor variasjon i bidragene. Noen utmerket seg ved at de hadde tenkt visuell profil hele veien, mens andre hadde fokusert mer på produktet. De seks finalistene holdt et meget høyt faglig nivå, og imponerte de erfarne lederne i finalejuryen. Finalejuryen besto av ordfører, kommunaldirektør og ledere av hjemmetjenesten og sykehjemmene i Skedsmo kommune. Juryen var enstemmig i sine valg av vinnerne. 


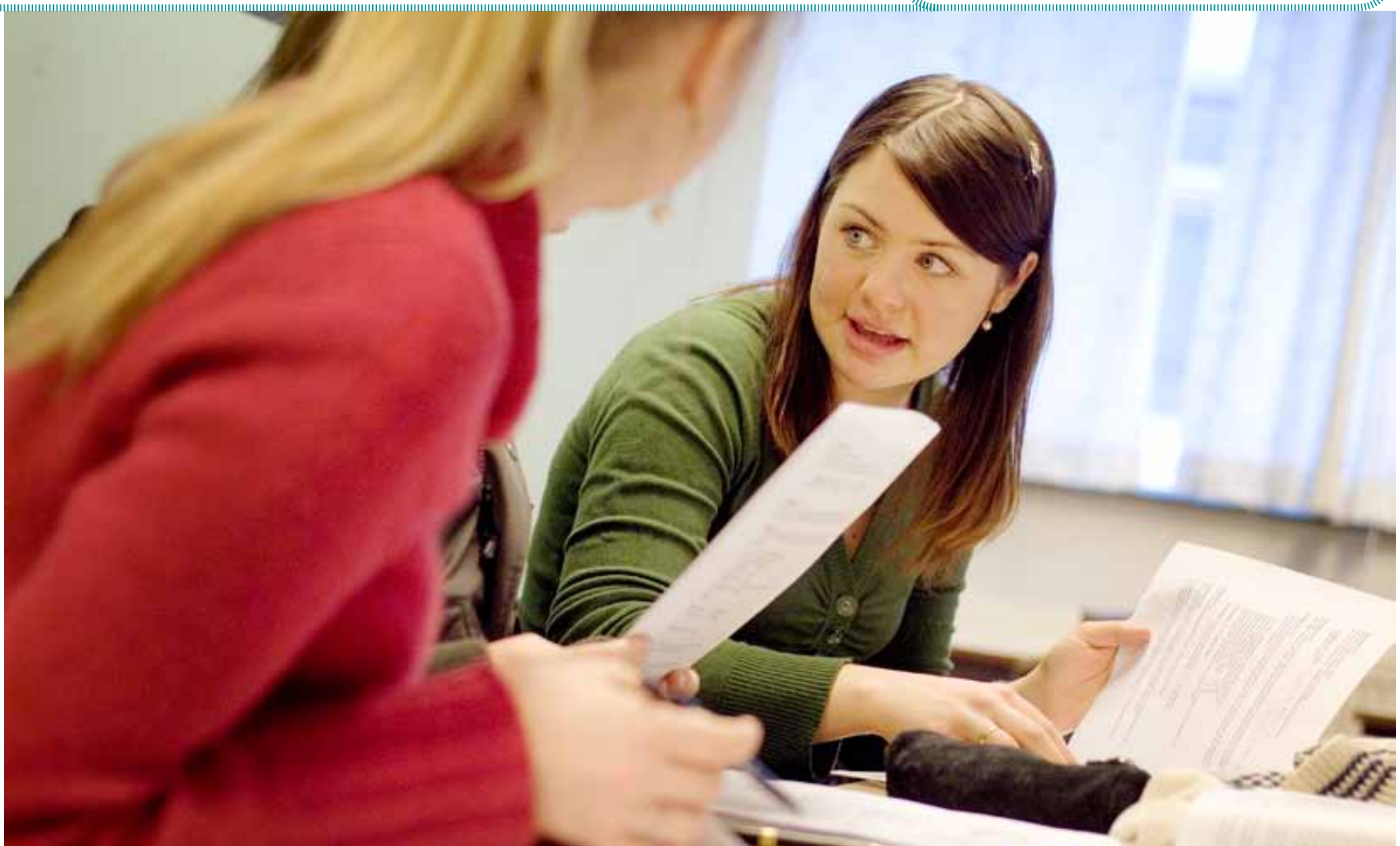

KREATIV LAERING: Entreprenøriell læring gir mulighet for kreativitet og engasjement og innebærer samarbeid på tvers av institusjoner. Arkivfoto: Stig M. Weston

\section{Vinnerne}

En gruppe vant prisen for beste kreative løsning. Juryen mente gruppen presenterte en gripende historie, og hadde en nyskapende og kreativ løsning med sin «Virituelle reise». Den hadde som mål å gjenskape pasientenes gode minner. Dette ble presentert ved hjelp av en flott visuell fremstilling i lyd og bilde. Prisen for den beste totale løsningen gikk til konseptet «Active Knowledge». Her var forslaget å opprette en database der frivillige kan registrere seg for å omgås sosialt med eldre pleietrengende. Løsningen vil gjøre nettverk og aktivitetsressurser lettere tilgjengelig for både pasienter og pleiepersonell. Databasen eies av kommunen og kan kople behov mot ressurser på tvers av tjenester.

Et eksempel var dersom en skoleelev ønsket å lære å strikke, kunne læreren søke i databasen etter noen som ønsket å lære bort dette. Kanskje fikk man treff på en eldre dame på sykehjemmet som kunne ha lyst til å hjelpe eleven med dette. Et annet eksempel kunne være en ungdomsskoleelev som trenger lesetrening. Denne kunne da matches med pasienter på sykehjemmet som gjerne vil bli lest for. På denne måten koples også generasjonene sammen på en konstruktiv måte.

\section{Erfaringer}

Studentenes tilbakemeldinger tilsier at dette var en utfordrende og morsom måte å lære på.
De opplevde både selve arbeidet med oppgaven, presentasjonen og foredragene som lærerikt. Flere var overrasket over hvor kreative deres medstudenter var, og fikk selv mange nye gode ideer. På avslutningsdagen uttalte de at det var morsomt å jobbe med nytenkning og kreativitet, og at denne måten å jobbe på ga økt selvtillit. I tillegg måtte de jobbe med samarbeidsevnen sin for å få til et godt konsept. Den klare tilbakemeldingen fra våre studenter var at gründercampen var krevende, morsom og nyskapende. «Dette vil vi ha mer av», var den unisone tilbakemeldingen.

Representantene fra Skedsmo kommune mente at flere av ideene som ble presentert kunne la seg gjennomføre, og gav tilbakemeldinger om at de ønsker å prøve ut flere av dem i praksis.

\section{Konklusjon}

Vi anbefaler å innføre gründercamp som pedagogisk metode også innenfor helse- og omsorgsutdanninger. Denne måten å arbeide på bidrar til å styrke samarbeid både studentene imellom og mellom høyskole og praksisfelt, samt å finne mulige løsninger på utfordringer i praksis gjennom innovasjon.

Entreprenøriell læring innebærer at sykepleierstudentene observerer, reflekterer over erfaringer og møter utfordringer på nye måter. Det

\section{«Det er behov for å ut- danne en ny generasjon helsepersonell.»}

var morsomt å se den skapergleden og kreativitet som viste seg både i studentenes samarbeid og i sluttproduktet på vår gründercamp.

Gründercamp bidrar til at studenter, næringsliv og lærere får nye og inspirerende ideer og lærer nye metoder. I tillegg kan disse relasjonene videreutvikles innenfor andre aktuelle områder. IIII

\section{REFERANSER}

Kunnskapsdepartementet (2009) Nasjonalt kvalifikasjonsrammeverk for livslang læring (NKR). Hentet fra http://www.regjeringen.no/upload/KD/Vedlegg/ Kompetanse/NKR2011mvedlegg.pdf

2. NOU 2011:11 (2011) Innovasjoniomsorg. Hentet frahttp://www.regjeringen.no/ nb/dep/hod/dok/nouer/2011/nou-2011-11.html?id=646812

3. St.meld. nr. 47(2008-2009) (2008). Samhandlingsreformen, Rett behandling - på rett sted - til rett tid. Hentet frahttp://www.regjeringen.no/nb/dep/hod/ dok/regpubl/stmeld/2008-2009/stmeld-nr-47-2008-2009-html?id=56720 4. Universitets-og høyskoleloven (2005) Lovomuniversiteter og høyskoler (Universitets- og høyskoleloven). Hentet fra: http://www.lovdata.no/all/hl-20050401015.htm

Fagartikler kan sendes til torhild.apall@sykepleien.no 